\title{
OPTIMAL ALLOCATION OF ACTIVE POWER FILTER ON REAL DISTRIBUTION NETWORKS FOR IMPROVEMENT OF POWER QUALITY BY USE OF BBO: A CASE STUDY
}

\author{
Emad Samadaei", Alireza KhosRavi ANd Abdolreza SHEIKHOleSlami \\ Department of Electrical and Computer Engineering, \\ Babol University of Technology Babol, Iran. \\ *Corresponding author: e.samadaei@stu.nit.ac.ir
}

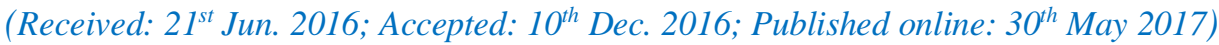

\begin{abstract}
With the development of power electronics devices, harmonic distortion has spread on the network. Harmonics are a threat to instruments and networks, and can decrease line capacity, etc. An Active Power Filter (APF) can be employed for harmonic compensation in power systems. In this paper, a distorted distribution feeder is considered and analyzed from a power quality viewpoint using a power analyzer device and it is then simulated in a MATLAB-Mfile. Then the size and placement of active power filters are determined by use of Biogeography Based Optimization (BBO). The goal of this optimization is minimizing losses and total harmonic distortion (THD) in the feeder by considering economical cost. Each approach's performance is assessed and appreciated with a case study on the Ghaemshahr-Iran Distribution network. Measurement is done on the city network with a CA8310 power analyzer. All data was collected on a computer then run through a $\mathrm{BBO}$ algorithm to select the best place and size for the active power filters. The results show a good performance.
\end{abstract}

ABSTRAK: Dengan pembangunan peranti elektronik kuasa, herotan harmonik telah merebak di dalam rangkaian. Harmonik adalah satu ancaman kepada instrumen dan rangkaian, dan boleh mengurangkan kapasiti talian, dan lain-lain. Satu Penapis Kuasa Aktif (APF) boleh digunakan untuk memampas harmonik dalam sistem kuasa. Dalam kertas ini, penyuap pengagihan terherot telah digunakan dan dianalisis dari sudut kualiti kuasa dengan menggunakan peranti penganalisa kuasa dan ia kemudian disimulasi dalam MATLAB-Mfile. Kemudian saiz dan penempatan penapis kuasa aktif ditentukan dengan menggunakan Pengoptimuman Berasaskan Biogeografi (BBO). Matlamat pengoptimuman ini adalah untuk mengurangkan kerugian dan jumlah herotan harmonik (THD) dalam penyuap dengan mengambil kira kos yang ekonomik. Prestasi setiap pendekatan ini akan dikaji dan ditaksir dengan satu kajian kes di dalam Rangkaian Pengagihan Ghaemshahr-Iran. Pengukuran akan dilakukan pada rangkaian bandar dengan penganalisis kuasa CA8310. Semua data yang dikumpulkan dalam komputer akan dikaji melalui algoritma $\mathrm{BBO}$ untuk memilih tempat dan saiz yang terbaik untuk penapis kuasa aktif. Hasil kajian menunjukkan prestasi yang baik.

KEYWORDS: power elctronics device; aloocation; active power filter; harmonics; distribution network; power quality

\section{INTRODUCTION}

Over the past few years, use of power electronic devices has increased power quality problems such as harmonic distortion and loss in residential and industrial distribution 
systems. Also, the power quality of the distribution system is affected by harmonics generated by non-linear loads. Linear loads such as incandescent bulbs or resistive heating consume a sinusoidal current that follows from the voltage source as a prefect wave shape against non-linear loads like arc furnaces, computers, SMPS (Switched Mode Power Supplies), fluorescent lamps with electronic ballasts, inverters, rectifiers, UPS (uninterruptible power supplies), TV, CFLS (compact fluorescent lamps), etc. Distortion is introduced as a current from the source that does not follow a sinusoidal wave shape. Voltage distortion increases in distribution systems [1]. The current harmonic goes to a nonsinusoidal voltage drop on the power system line conductors, so a voltage distortion is generated. Voltage distortion can increase the resonance probability in a power system. The resonance of the capacitor banks with the distribution system impedance at a specific harmonic frequency may lead to destroyer affects in all of the power system equipment [2]. In addition, harmonic currents can cause the failures of circuit breakers and protection devices under certain operating conditions [3]. In [4], impact of fluorescent lights on the distribution system is investigated from a harmonic distortion viewpoint. Distribution network reconfiguration (DNR), capacitor switching, and installation of passive filters are routine solutions for the limitation of harmonic distortion.

Recently, a widespread increase in the number of power electronics systems is responsible for a higher level of harmonic distortions in distribution networks. Many papers intended to provide a comprehensive view of the status of topological aspects of techniques used to improve the power quality in distribution networks for researchers, designers, and engineers working in this area [5]. For this reason, the aforementioned solutions for large sources of harmonics may become unsuitable and ineffective. Therefore, the active power filter (APF) is presented as an effective solution for perfect control of harmonic levels in distribution systems. APF is an advanced device based on power electronic techniques and digital signal processing (DSP). In comparison to customary passive filters, APF includes some typical merits, for example: the filtering process will not be affected by system impedance. Series or parallel resonance won't happen with system impedance. Also, a change of system structure will not influence the outcome and the increase of harmonic value won't lead to overload. In [6], a plan is introduced to apply APF to produce inverse harmonic currents to reduce the amount of harmonic distortion and resonant occurrence possibility. In [7], the harmonic impact of modern residential loads on secondary power distribution systems is studied. In [8], an enhanced current control approach is proposed that seamlessly integrates system harmonic mitigation capabilities with the primary DG power generation function. In [9], a genetic algorithm and a feasible direction method are applied for optimal planning of harmonic filters with uncertainty conditions. An optimal method for active power filter is presented in [10] to improve power quality. The control system of the APF is based on a combination of the synchronous detection method, instantaneous power theory, and output of a DC capacitor voltage regulator. The efficiency of the control algorithms such as synchronous detection and indirect current control for active power filters is analyzed in [11] and an efficient control algorithm is developed by the Xilinx system generator which is incorporated into Simulink as the Xilinx tool box. A strategy was proposed for the combined system of passive shunt and active series filters in [12]. In [13], two algorithms are proposed for optimum allocation and sizing of APFs in power systems. In both algorithms, genetic algorithm (GA) is applied as the optimization tool. Research from [14] presents a new hybrid method based on biogeography-based optimization (BBO) to solve harmonic estimation problems in cases of time varying power signals in presence of different noises. BBO is used for other applications to optimize allocation of DGs and capacitors considering harmonic pollution [15]. 
In this paper, optimal places and sizes of active power filters (APFs) are determined for harmonic distortion and loss reduction, and voltage profile improvement on a case study distribution system (20/0.4KV SAJJAD feeder of distribution system of Ghaemshahr city in Iran) using bio geographical based optimization (BBO [16]). The simulation and practical test results show that the optimal allocation of APFs in distribution networks would enhance all of the power quality parameters: reduce losses extremely, save energy, decrease neutral current, and release distribution lines and transformers from overload due to harmonic currents and reactive power.

\section{POWER QUALITY PARAMETERS MEASUREMENT IN THE SAJJAD FEEDER IN GHAEMSHAHR (CASE STUDY)}

During the implementation of this project, the SAJJAD feeder was known as a polluted feeder in Ghaemshahr in terms of harmonic distortion. The main reasons for this choice included its location in a downtown area with mixed commercial - residential loads as well as loads with high harmonic generation Fig. 1 shows the topologie of SAJJAD feeder. The test duration for each substation is 24 hours. Sampling is done every 30 minutes. Also, the test is performed on non-holidays. Low voltage distribution transformers are tested by the Chauvin Arnoux Power \& Harmonic Analyzer system (CA8310) (Fig. 2 and Fig. 3). The Test Parameters include voltage (V), Current (I), active power (P), reactive power (Q), power factor (PF); THD voltage and current (total harmonic distortion) and harmonic orders from 1 to 25 . The test results are presented separately for each substation in Table A1 (appendix). Figure 1 shows a Single-line diagram of the SAJJAD feeder.

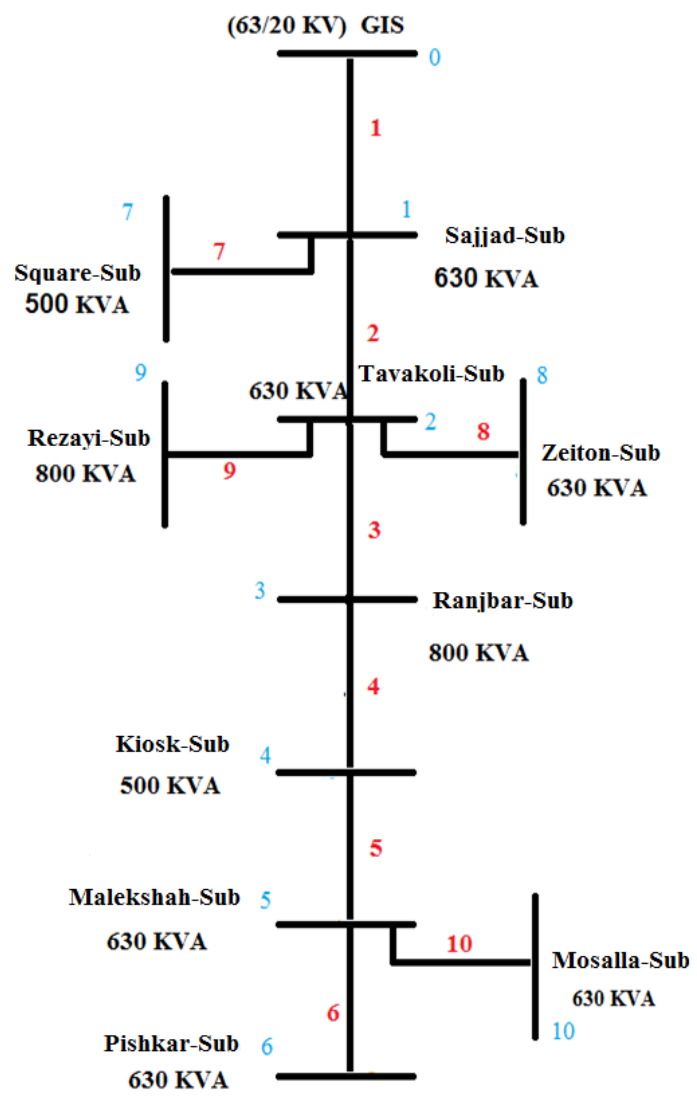

Fig. 1: Single-line diagram of the SAJJAD feeder. 


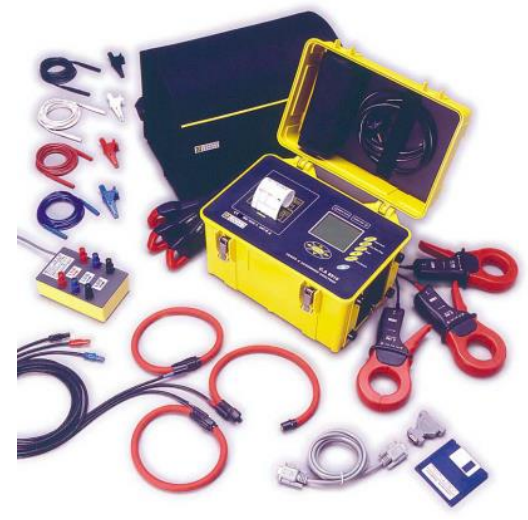

Fig. 2: Power \& harmonic analyzer system (CA8310).

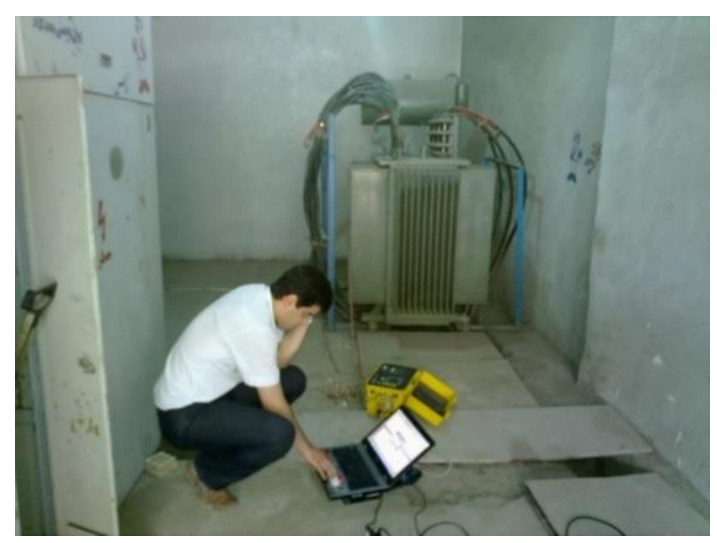

Fig. 3: Sample image of test.

The results presented in Table A1 show that the network status doesn't follow standard IEEE519 (THD value should be less than 8\%). This can cause serious damage to the network and subscribers. THD flow rate is very high in the Ranjbar, Tavakkoli, Zeitun and Pishkar substations. Table A1 in the appendix shows that feeder draws large amounts of current from the network because of harmonics. Losses per phase or per LV (Low Voltage) sub have been shown in the last column in Table A1. In general, Losses per phase are caused by harmonics equal to 217246.046 (Volt-Amperes). In considering the power consumption of the SAJJAD feeder 1780568.47 (Volt-Ampere), harmonic losses are about $12.20 \%$. The volt-ampere unit is used to calculate the harmonic power losses because the analyzer device doesn't extract the power factor of each harmonic separately. This percentage is related to the direct harmonic damage to the network. Indirect damages are caused by harmonics including reducing the life of the network and consumer equipment, capacity occupation of distribution transportation lines and transformers, and the cost of new transportation line structure and repairs. Such damages are extremely expensive.

Figure 4 shows THD column Chart for each single phase in the studied feeder. Chart reveals that R-phase in Ranjbar substation and T-phase in Tavakolli substation has exceeded the Harmonics standards. In addition, it has caused an unbalancing problem in the mentioned substations. Also, the chart describes how the network is extremely polluted from the harmonic distortion viewpoint, except in Pishkar and Malekshah substations, in the two phase (S-phase and T-phase) in Ranjbar substation, and in the R-phase and T-phase in the Tavakkoli substation. The nonlinear electrical loads are the mainspring of these distortions in distribution systems. Hence, compensation should be done in order to prevent harmonic losses and damages. In order to use the results and choose appropriate values for APFs currents, one should consider that the 3rd harmonic and its multiples remove from MV (Medium Voltage) side of transformers using star or triangle connection. In these harmonics, it is not necessary to use an active filter. In order to select the optimal size of the active filter, one must consider an important and permanent harmonic in networks such as 5, 7, 11, or 13. Use of APF is more effective to the network during peak hours, thus considering the size of the harmonics during peak hours is logical for choosing the optimal size of the APF.

Simulation was performed of the load flow for the SAJJAD Feeder in Matlab R2010a (M-file) software while applying practical test value results obtained by the power analyzer device (active and reactive power, harmonic currents) as input in the simulation. Output values, including harmonic voltage and amount of voltage in a comparison with 


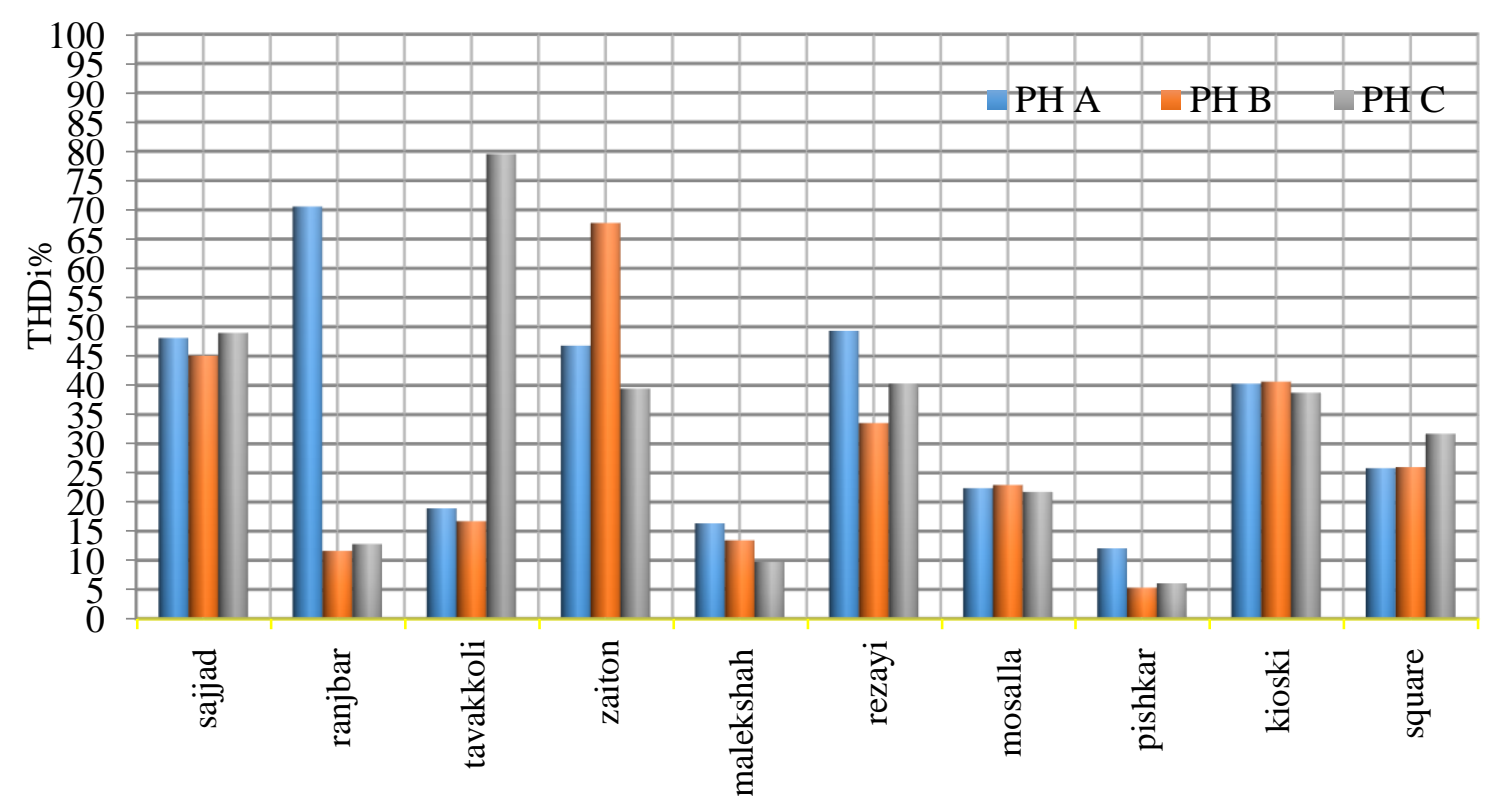

Fig. 4: Current THD column Chart for each single phase in the SAJJAD feeder.

the actual test output, are shown in Table.1 to validate simulation accuracy. Some details, such as tap changer and clamps between lines, that were considered in the implementation of the SAJJAD feeder were not available for the beneficiary. Consequently, it could not be measured and calculated, leading to a negligible difference between simulation and actual results. Obviously, it has no impact on the active filter selection that is the ultimate goal of this project. System simulation in MATLAB with reasonable accuracy is verified in Table1. Thus, these simulations can be used to implement the next steps i.e. searcher algorithms in order to select the APFs for the appropriate substations.

\section{OPTIMAL PLACEMENT OF ACTIVE POWER FILTERS (APFS) USING BBO}

The objective of the simulation is the best location of active filters on the SAJJAD feeder in Ghaemshahr city. In this procedure, maximum loss reduction traces by active filter usage on the LV side should be determined. Since the active filters are the sources of reverse harmonic current, they could be modeled as a current source in each harmonic. Harmonic currents for each active filter at network are shown with $I_{f m}^{h}$ where $\mathrm{m}$ is the substation number and $\mathrm{h}$ is the harmonic level. The RMS currents of each active filter could be obtained with the Eqn. (1):

$$
I_{f m}=\left[\sum_{h}^{H}\left(\begin{array}{ll}
h \\
f m
\end{array}\right)^{2}\right]^{1 / 2}
$$

The main goal of this optimization is current harmonic reduction, loss reduction, and improvement in output voltages and current waveforms from a distortion viewpoint throughout the feeder.

The HSI (objective function) of this problem is shown in Eqn. (2): 


$$
\mathrm{HSI}=\min \left(\left(\sum_{1}^{m}\left(T H D i_{m} \times \frac{I_{m}^{F}}{\text { Ifund }}\right)^{2}\right)^{\frac{1}{2}}\right)
$$

Where, $\left(\frac{I_{m}^{F}}{\text { Ifund }}\right)$ is the weighting factor parameter. So a substation with higher current has more effect on the amount of the objective function (HSI). It means that there are more chances for the above substations to select and participate in the BBO process. $I_{m}^{F}$ is the flow of primary frequency current (I Fundamental) in substation number $m$ that is caused by load.

Table 1: Effective harmonic voltage values, simulated voltage and comparison with actual test results

\begin{tabular}{|c|c|c|c|c|c|c|}
\hline $\begin{array}{l}\text { accuracy } \\
\text { of the } \\
\text { simulation } \\
\mathrm{V}(\%) \\
\text { (rounded) }\end{array}$ & $\begin{array}{c}\text { Phase } \\
\text { Voltage } \\
\text { (real } \\
\text { value) }\end{array}$ & $\begin{array}{c}\text { Phase } \\
\text { Voltage } \\
\text { (simulation) }\end{array}$ & $\begin{array}{c}\text { THDv e } \\
\text { (effective value } \\
\text { of voltage Total } \\
\text { harmonic } \\
\text { distortion) } \\
\text { (real value) }\end{array}$ & $\begin{array}{c}\text { THDv e } \\
\text { (effective value } \\
\text { of voltage Total } \\
\text { harmonic } \\
\text { distortion) } \\
\text { (simulation) } \\
\end{array}$ & & Sub name \\
\hline $1 \%$ & 223.4 & 220.05 & 1.8 & 1.53 & $\mathrm{R}$ & \multirow{3}{*}{$\begin{array}{c}\text { Sajjad } \\
20 / 0.4 \text { KV }\end{array}$} \\
\hline $2 \%$ & 226.7 & 221.97 & 1.8 & 1.26 & S & \\
\hline $3 \%$ & 227 & 220.51 & 2 & 1.46 & $\mathrm{~T}$ & \\
\hline $4 \%$ & 225.3 & 215.87 & 2.6 & 2.11 & $\mathrm{R}$ & \multirow{3}{*}{$\begin{array}{c}\text { Ranjbar } \\
\text { 20/0.4 KV }\end{array}$} \\
\hline $4 \%$ & 227.7 & 219.26 & 2 & 1.64 & $\mathrm{~S}$ & \\
\hline $5 \%$ & 229.1 & 217.54 & 3.1 & 2.11 & $\mathrm{~T}$ & \\
\hline $3 \%$ & 225.6 & 218.51 & 1.6 & 1.74 & $\mathrm{R}$ & \multirow{3}{*}{$\begin{array}{l}\text { Tavakkoli } \\
\text { 20/0.4 KV }\end{array}$} \\
\hline $4 \%$ & 228.9 & 220.79 & 1.3 & 1.43 & $\mathrm{~S}$ & \\
\hline $2 \%$ & 224 & 219.12 & 1.8 & 1.66 & $\mathrm{~T}$ & \\
\hline $5 \%$ & 228.6 & 218.22 & 1.3 & 1.78 & $\mathrm{R}$ & \multirow{3}{*}{$\begin{array}{c}\text { Zeiton } \\
\text { 20/0.4 KV }\end{array}$} \\
\hline $3 \%$ & 227.9 & 220.42 & 1.4 & 1.48 & S & \\
\hline $5 \%$ & 229.5 & 218.94 & 1.4 & 1.69 & $\mathrm{~T}$ & \\
\hline $4 \%$ & 223 & 215.11 & 2 & 2.22 & $\mathrm{R}$ & \multirow{3}{*}{$\begin{array}{c}\text { Malekshah } \\
20 / 0.4 \text { KV }\end{array}$} \\
\hline $3 \%$ & 224.5 & 218.56 & 2 & 1.74 & $\mathrm{~S}$ & \\
\hline $3 \%$ & 223.3 & 216.89 & 1.7 & 1.96 & $\mathrm{~T}$ & \\
\hline $4 \%$ & 227.4 & 218.28 & 1.3 & 1.78 & $\mathrm{R}$ & \multirow{3}{*}{$\begin{array}{c}\text { Rezayi } \\
\text { 20/0.4 KV }\end{array}$} \\
\hline $3 \%$ & 227.3 & 220.60 & 1.4 & 1.46 & $\mathrm{~S}$ & \\
\hline $2 \%$ & 223.9 & 218.89 & 1.2 & 1.7 & $\mathrm{~T}$ & \\
\hline $5 \%$ & 226.7 & 215.24 & 1.6 & 2.20 & $\mathrm{R}$ & \multirow{3}{*}{$\begin{array}{c}\text { Mosalla } \\
\text { 20/0.4 KV }\end{array}$} \\
\hline$-2 \%$ & 215.4 & 218.65 & 1.5 & 1.72 & $\mathrm{~S}$ & \\
\hline $5 \%$ & 228.7 & 216.95 & 2.7 & 1.95 & $\mathrm{~T}$ & \\
\hline $7 \%$ & 230.3 & 215.04 & 1.2 & 2.23 & $\mathrm{R}$ & \multirow{3}{*}{$\begin{array}{c}\text { Pishkar } \\
\text { 20/0.4 KV }\end{array}$} \\
\hline $4 \%$ & 228.8 & 218.53 & 2 & 1.74 & S & \\
\hline $5 \%$ & 229.1 & 216.85 & 1.6 & 1.97 & $\mathrm{~T}$ & \\
\hline $4 \%$ & 225.5 & 215.36 & 1.8 & 2.18 & $\mathrm{R}$ & \multirow{3}{*}{$\begin{array}{c}\text { Kiosk } \\
20 / 0.4 \text { KV }\end{array}$} \\
\hline $3 \%$ & 225.5 & 218.79 & 1.4 & 1.7 & S & \\
\hline $2 \%$ & 221.8 & 217.09 & 1.7 & 1.93 & $\mathrm{~T}$ & \\
\hline $5 \%$ & 232.4 & 219.90 & 1.7 & 1.55 & $\mathrm{R}$ & \multirow{3}{*}{$\begin{array}{c}\text { Square } \\
20 / 0.4 \mathrm{KV}\end{array}$} \\
\hline$-1 \%$ & 220.5 & 221.82 & 1.4 & 1.28 & S & \\
\hline $0 \%$ & 219.3 & 220.33 & 1.8 & 1.49 & $\mathrm{~T}$ & \\
\hline
\end{tabular}




\subsection{The System Limits}

1- Each active filter can deliver a limit effective current that is known as the filter size. The limitation in maximum injection of active filters should be considered.

2- Harmonic standards (IEEE519), apply on harmonic voltages and the total harmonic distortion (THD) coefficient in different points of the network. (The amount of THD should be lower than $8 \%$ and the amount of each Harmonic order should be lower than 5\%.) A random habitat for optimal placement of one active filter in the SAJJAD feeder by BBO is shown in Fig. 5:

\begin{tabular}{|c|c|c|c|c|}
\multicolumn{1}{c|}{ h5 } & \multicolumn{1}{c}{ h7 } & \multicolumn{1}{c}{ h11 } & \multicolumn{1}{c}{ h13 } & Sub. No \\
\hline 36.66 & 19 & 12.42 & 4.12 & 8 \\
\hline
\end{tabular}

Fig. 5: Representation of a habitat (in BBO process) for optimal placement problem.

In Fig.5, from left (h5, h7, h11, h13), numbers that are shown are fifth, seventh, eleventh, and thirteenth harmonic orders that are injected on substation number 8 by active filter. It is obvious that the maximum amount for each harmonic current can be equal to the amount of harmonic current that is taken in that substation's load. Because the active filter is intelligent and self-regulating, the current can regulate itself by power-electronic circuits in order to avoid a greater flow than the load current.

The simulation has been done in a MATLAB-Mfile as in Fig. 6. The results of the simulation have been applied with the supposition that an active power filter may be in any phase in the studied feeder. Also, the amount of the objective function and the network voltage profile has been represented after placement of the filters. Due to the load unbalancing in the network, the fixing of the three-phase APF may not be economical. For example, the $\mathrm{R}$ phase in a substation may have large amounts of harmonic current while the amount of the harmonic current of the $\mathrm{S}$ and $\mathrm{T}$ phases in the same substation maybe low. Thus, the utilization of the three-phase APF is not economical in this substation.

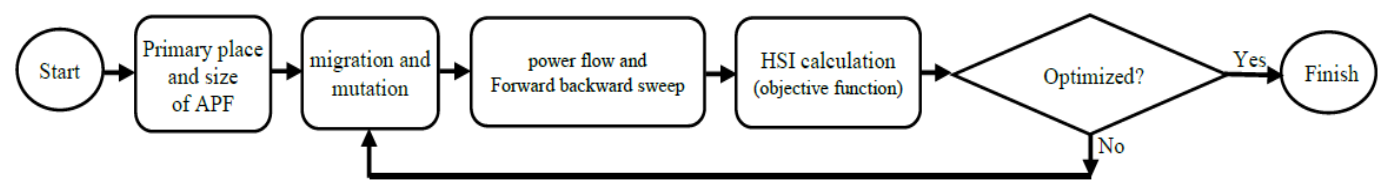

Fig. 6: The flowchart of optimal placement of active power filters (APFs) using BBO.

Table 2: Current (power) and emplacement of active filter gained from software simulation results by use of $\mathrm{BBO}$

\begin{tabular}{cccc}
\hline $\mathbf{T}$ & $\mathbf{S}$ & $\mathbf{R}$ & \\
\hline- & - & 35.17 & Ranjbar Su 20/0.4 KV \\
34.14 & - & - & Tavakkoli Sub 20/0.4 KV \\
- & 31.73 & - & Zeitun Sub 20/0.4 KV \\
\hline
\end{tabular}

The utilized power of the substation and the phase where the active power filter is installed are shown in Table 2, and these are obtained by search algorithm (BBO). At this stage, one APF is used for each phase, i.e. 35.17(A), 31.73(A) and 34.14(A) active power filters are located at the $\mathrm{R}$ phase of the Ranjbar substation, the $\mathrm{S}$ phase of Zeitun substation, and the $\mathrm{T}$ phase of the Tavakkoli substation. Using these 3 active power filters results in 
improvement of power quality as shown in Fig. 7 and Fig. 8. Here, the loss has reduced from 217.24646 KVA to 190.66537 KVA.

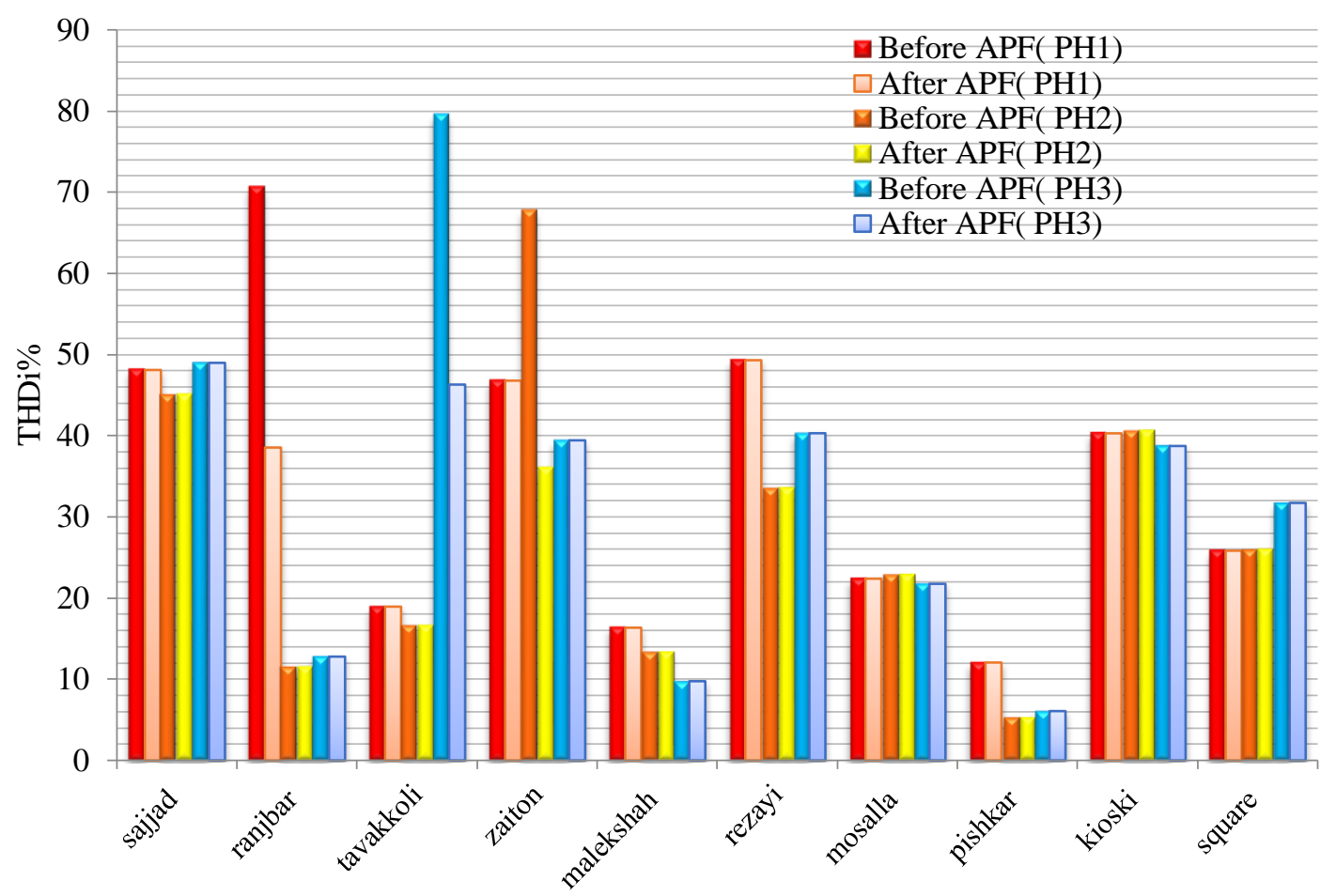

Fig. 7: Column chart of the \%THD phase current for each substation, with and without active power filter (one active filter per each phase).

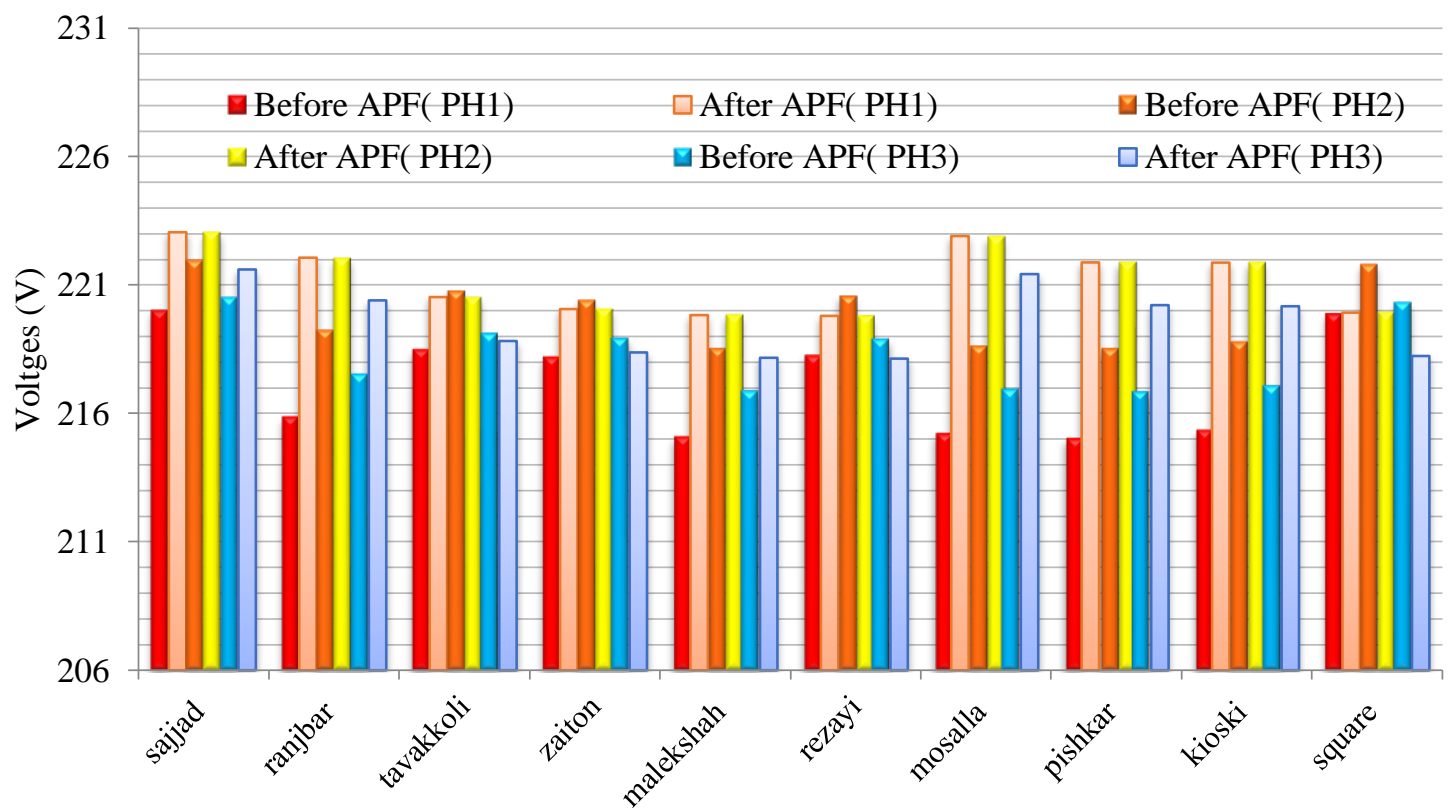

Fig. 8: Comparative column chart of the phase voltage for each substation, with and without active power filter (one active filter per each phase). 
By implementing active filters, it is expected that the harmonic current in these phases has somehow been compensated for, as Fig. 7 proves. Figure 7 compares the amount of harmonic distortion of each phase from each substation with and without active filter. For each substation, 6 bars have shown that the $1 \mathrm{st}, 3^{\text {rd }}$, and 5 th bar are for phase R, S, and T respectively without active filter and the $2 \mathrm{nd}, 4^{\text {th }}$, and 6 th bar are for phase $\mathrm{R}, \mathrm{S}$, and $\mathrm{T}$ respectively, with the active filter. Furthermore, Fig. 8 shows that the phase voltage has been improved due to the use of active filters and a voltage drop has been applied as compensation. The loss of each harmonic is depicted separately in Fig. 9, in which the presence of one APF per phase results in a $1.49 \%$ decrement of the total loss.

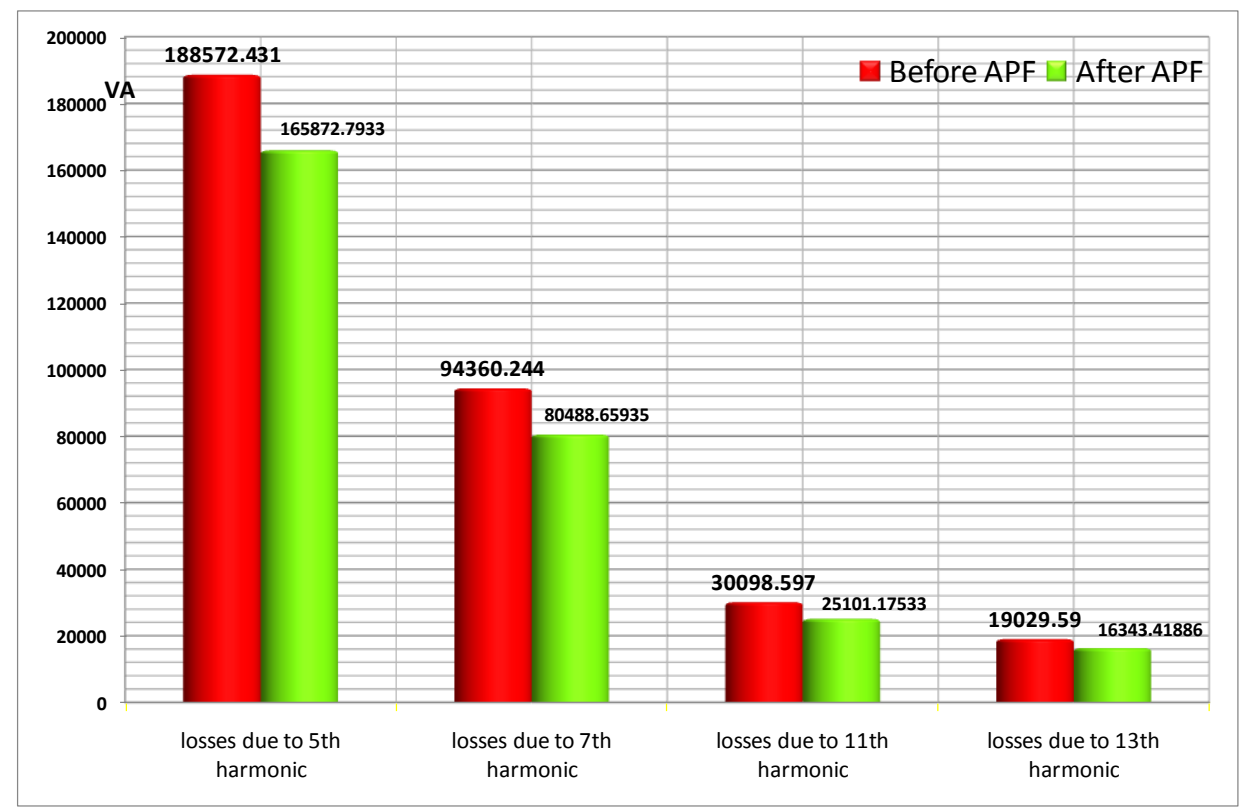

Fig. 9: Loss of each harmonic (i.e. 5, 7, 11, and 13) with and without active power filter (one active filter per phase).

\subsubsection{Results Determining Optimal Size and Placement of APF in the Network using BBO}

According to the results of the last section, it's probable that using the more APF can greatly improve the power quality however, it increases the order cost. So an index should be specified to consider the most optimal number of installed APF. This index can be standardized according to price, which, if the price of economized energy in the presence of APF in a year is more than the price of buying the APF, will provided more optimal and economical results. According to these explanations, the results have been limited to 2 to 5 APF per phase, with results shown in Figs. 10 to 15 and Tables 3 to 6.

\subsubsection{Results for Two Active Power Filters in Each Phase}

Table 3: The amount of current and location of installation for two active power filters

\begin{tabular}{cccl}
\hline $\mathbf{R}$ & $\mathbf{S}$ & $\mathbf{T}$ & \\
\hline 17.70 & - & - & $20 / 0.4 \mathrm{KV}$ Sajjad sub \\
- & - & 37.02 & $20 / 0.4 \mathrm{KV}$ Ranjbar sub \\
31.52 & - & - & $20 / 0.4 \mathrm{KV}$ Tavakkoli sub \\
- & 40.34 & - & $20 / 0.4 \mathrm{KV}$ Zeitun sub \\
- & - & - & $20 / 0.4 \mathrm{KV}$ Malekshah sub
\end{tabular}

\begin{tabular}{cccl}
\hline R & S & T & \\
\hline- & - & 24.08 & $20 / 0.4 \mathrm{KV}$ Rezayi sub \\
- & - & - & $20 / 0.4 \mathrm{KV}$ Mosalla sub \\
- & - & - & $20 / 0.4 \mathrm{KV}$ Pishkar sub \\
- & 9.36 & - & $20 / 0.4 \mathrm{KV}$ Kiosk sub \\
- & - & - & $20 / 0.4 \mathrm{KV}$ Square sub \\
\hline
\end{tabular}




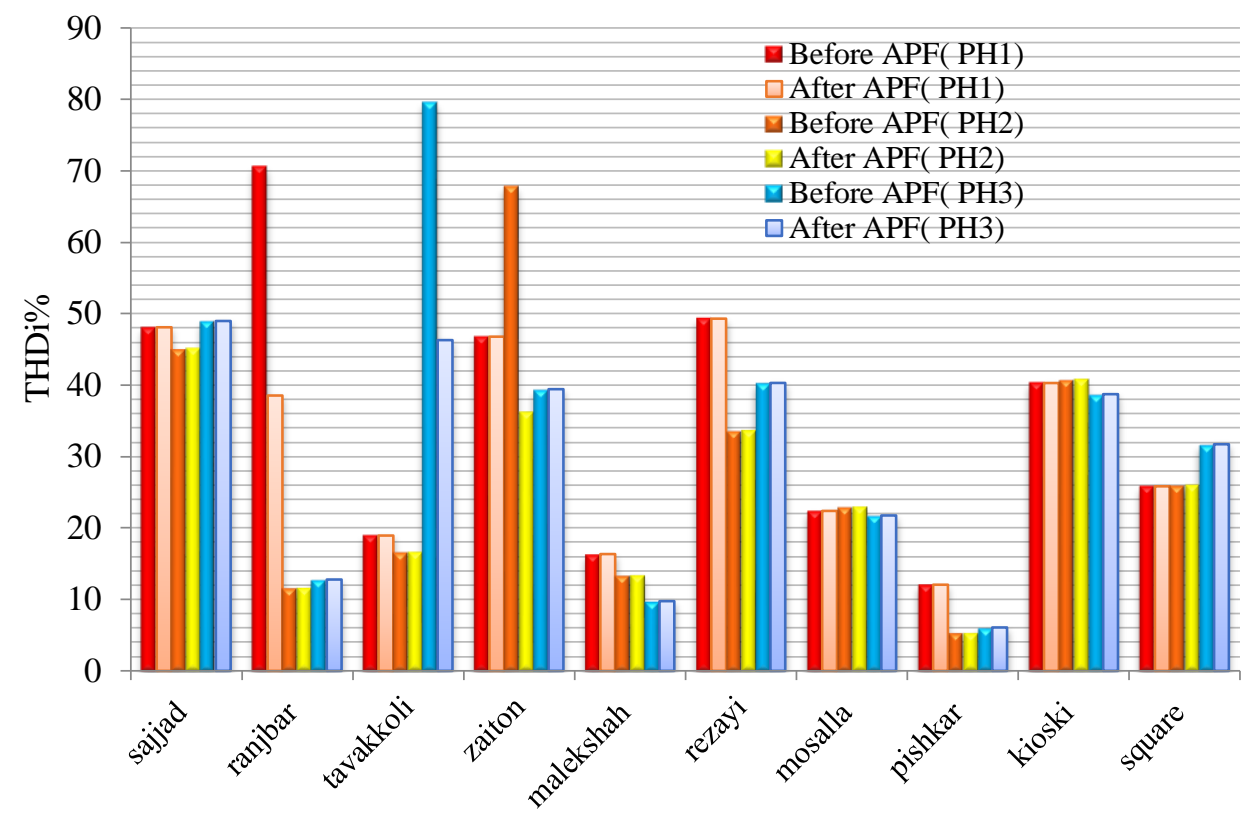

Fig. 10: Column chart of the \%THD phase current for each substation, with and without active power filter (two active filters per phase).

\subsubsection{Results for Three Active Power Filters in Each Phase}

Table 4: The amount of current and location of installation for three active power filters

\begin{tabular}{cccl}
\hline $\mathbf{R}$ & $\mathbf{S}$ & $\mathbf{T}$ & \\
\hline- & 28.19 & 12.38 & $20 / 0.4 \mathrm{KV}$ Sajjad sub \\
- & - & 31.04 & $20 / 0.4 \mathrm{KV}$ Ranjbar sub \\
34.35 & - & - & $20 / 0.4 \mathrm{KV}$ Tavakkoli sub \\
27.86 & 34.85 & 36.96 & $20 / 0.4 \mathrm{KV}$ Zeitun sub \\
- & - & - & $20 / 0.4 \mathrm{KV}$ Malekshah sub \\
\hline
\end{tabular}

\begin{tabular}{cccl}
\hline R & S & T & \\
\hline 9.75 & - & - & 20/0.4 KV Rezayi sub \\
- & - & - & 20/0.4 KV Mosalla sub \\
- & - & - & 20/0.4 KV Pishkar sub \\
- & 6.05 & - & 20/0.4 KV Kiosk sub \\
- & - & - & 20/0.4 KV Square sub \\
\hline
\end{tabular}

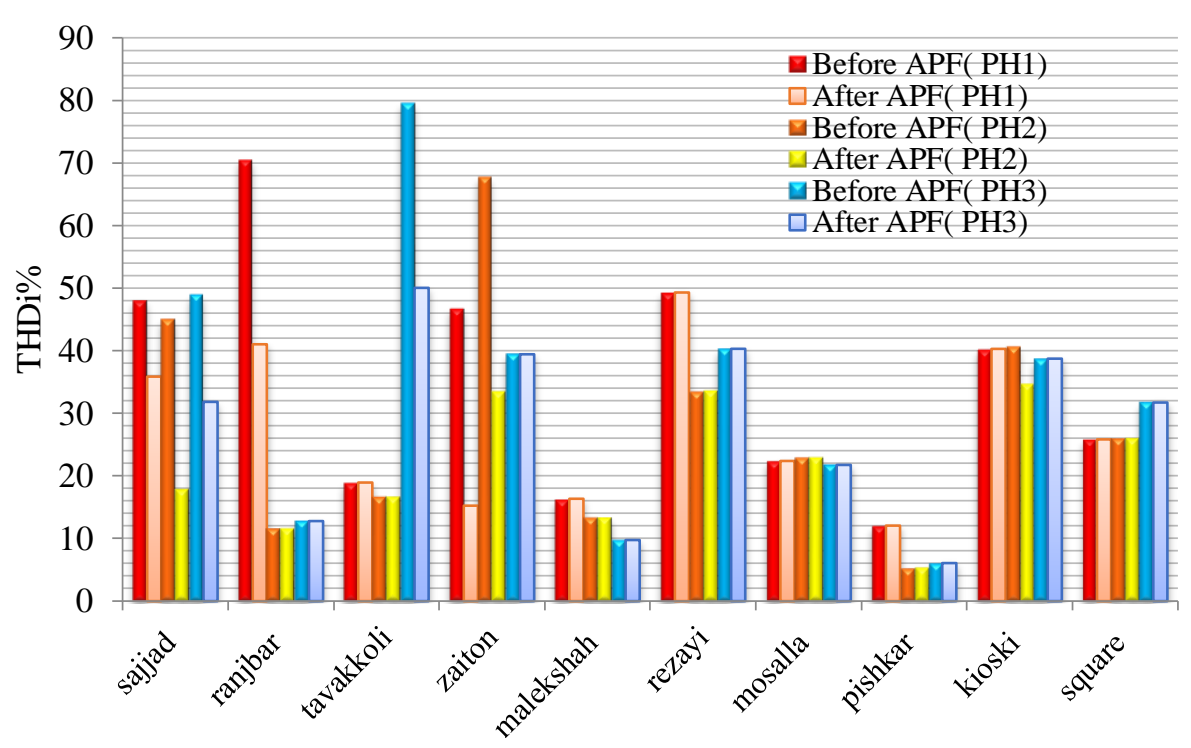

Fig. 11: Column chart of the \%THD phase current for each substation, with and without active power filters (three active filters per phase). 


\subsubsection{Results for Four Active Power Filters in Each Phase}

Table 5: The amount of current and location of installation for four active power filters

\begin{tabular}{cccl}
\hline $\mathbf{R}$ & $\mathbf{S}$ & $\mathbf{T}$ & \\
\hline- & - & 20.39 & $20 / 0.4 \mathrm{KV}$ Sajjad sub \\
- & - & 33.93 & $20 / 0.4$ KV Ranjbar sub \\
37.45 & - & - & 20/0.4 KV Tavakkoli sub \\
23.23 & 45.16 & 33.08 & $20 / 0.4$ KV Zeitun sub \\
- & - & - & 20/0.4 KV Malekshah sub \\
\hline
\end{tabular}

\begin{tabular}{cccl}
\hline $\mathbf{R}$ & $\mathbf{S}$ & $\mathbf{T}$ & \\
\hline- & 21.44 & - & 20/0.4 KV Rezayi sub \\
- & - & - & 20/0.4 KV Mosalla sub \\
5.87 & - & - & 20/0.4 KV Pishkar sub \\
- & 23.79 & 32.22 & 20/0.4 KV Kiosk sub \\
9.54 & 22.80 & - & 20/0.4 KV Square sub \\
\hline
\end{tabular}

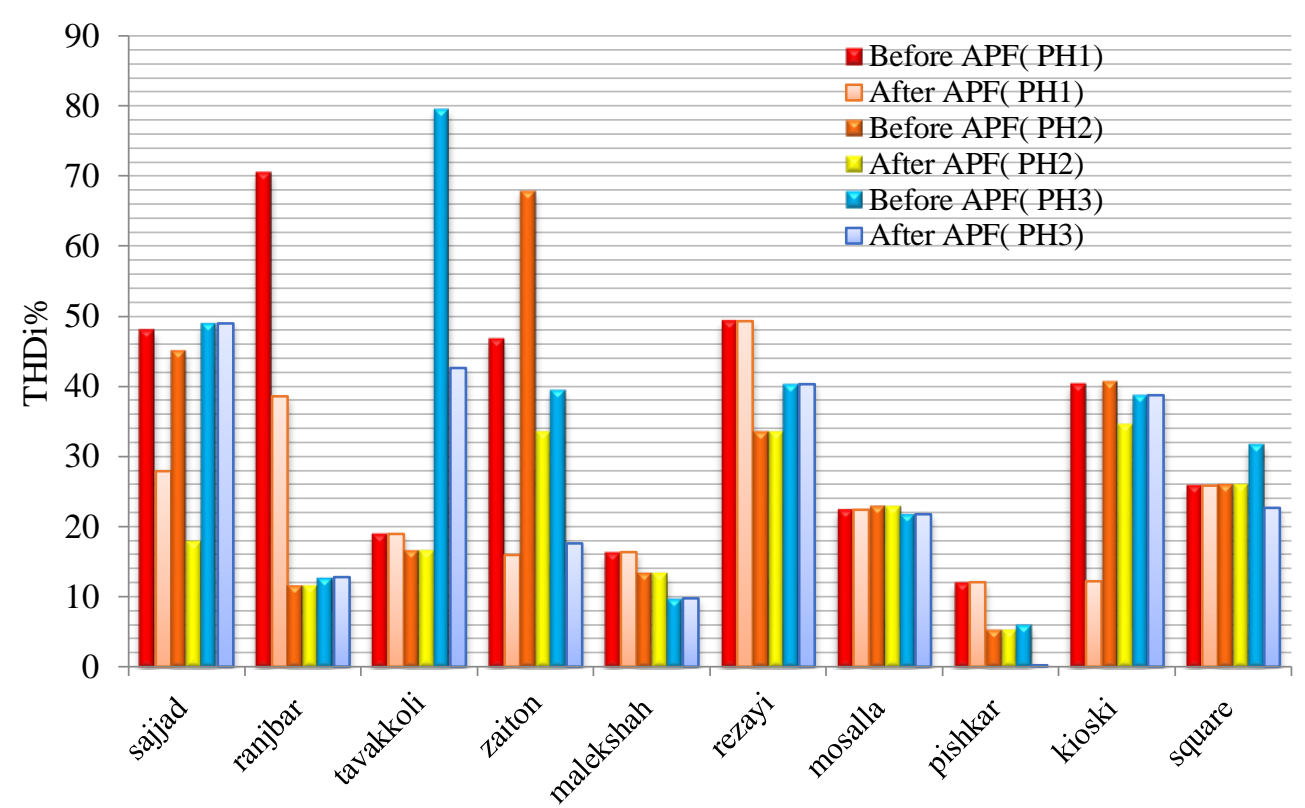

Fig. 12: Column chart of the \%THD phase current for each substation, with and without active power filters (four active filters per phase).

\subsubsection{Results for Five Active Power Filters (APF) in Each Phase}

Table 6: The amount of current and location of installation for five active power filters

\begin{tabular}{cccl}
\hline $\mathbf{R}$ & $\mathbf{S}$ & $\mathbf{T}$ & \\
\hline 12.25 & 26.73 & 23.01 & $20 / 0.4 \mathrm{KV}$ Sajjad sub \\
- & - & 27.41 & $20 / 0.4 \mathrm{KV}$ Ranjbar sub \\
42.96 & 7.14 & - & $20 / 0.4 \mathrm{KV}$ Tavakkoli sub \\
19.18 & 45.20 & 31.15 & $20 / 0.4 \mathrm{KV}$ Zeitun sub \\
- & - & - & $20 / 0.4 \mathrm{KV}$ Malekshah sub \\
\hline
\end{tabular}

\begin{tabular}{cccl}
\hline $\mathbf{R}$ & $\mathbf{S}$ & $\mathbf{T}$ & \\
\hline 15.57 & 25.00 & 21.88 & $20 / 0.4 \mathrm{KV}$ Rezayi sub \\
- & - & - & $20 / 0.4 \mathrm{KV}$ Mosalla sub \\
6.05 & 5.32 & - & $20 / 0.4 \mathrm{KV}$ Pishkar sub \\
- & - & 9.66 & $20 / 0.4 \mathrm{KV}$ Kiosk sub \\
- & - & - & $20 / 0.4 \mathrm{KV}$ Square sub \\
\hline
\end{tabular}

In Fig.14 and Fig.15, the amount of harmonic losses for different numbers of APFs per phase has been shown on the diagram explaining that when increasing in number of APFs in the feeder, there is a significant decrement in losses from $\% 12.2$ to $\% 8.41$. 


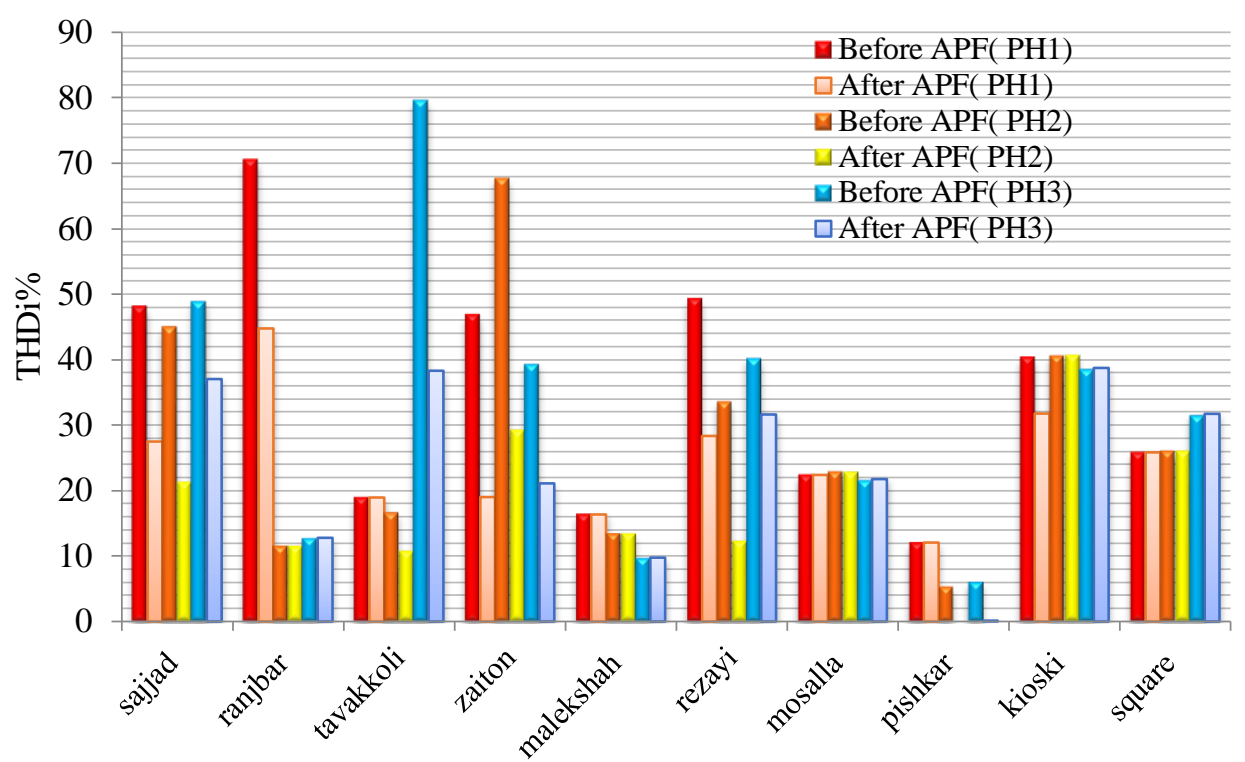

Fig. 13: Column chart of the \%THD phase current for each substation, with and without active power filters (five active filters per phase).

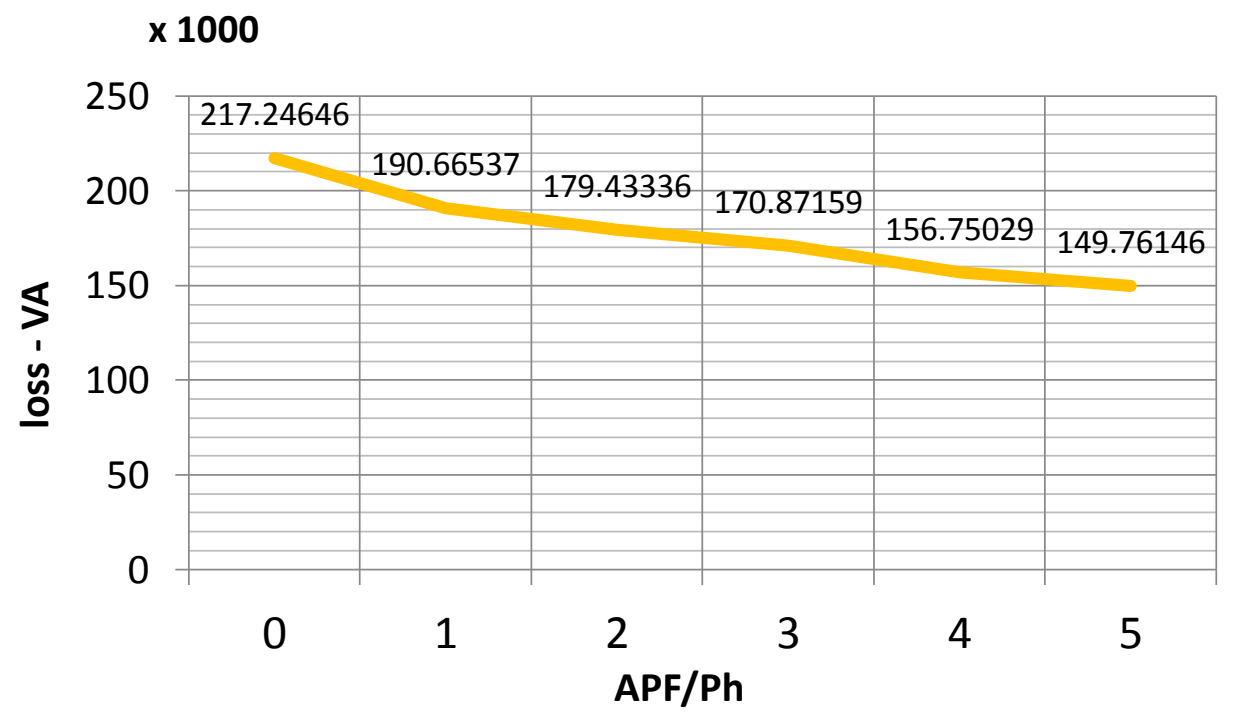

Fig. 14: Harmonic loss comparison curve in terms of the numbers of active power filters in each phase.

If the average production cost of a KW of electricity power is assumed to be 1000 dollars and the average price of buying an APF assumed to be 100 dollars per ampere, Table 7 shows the index rate for the price of conserved energy with APF on the rate of price to buy APF for each of the five cases.

Table 7: Index for energy cost saving with APF on cost of its procurement

\begin{tabular}{cccccc}
\hline 5 & 4 & 3 & 2 & 1 & Number of APF \\
\hline 2.11 & 1.95 & 2.09 & 2.36 & 2.63 & financial index \\
\hline
\end{tabular}




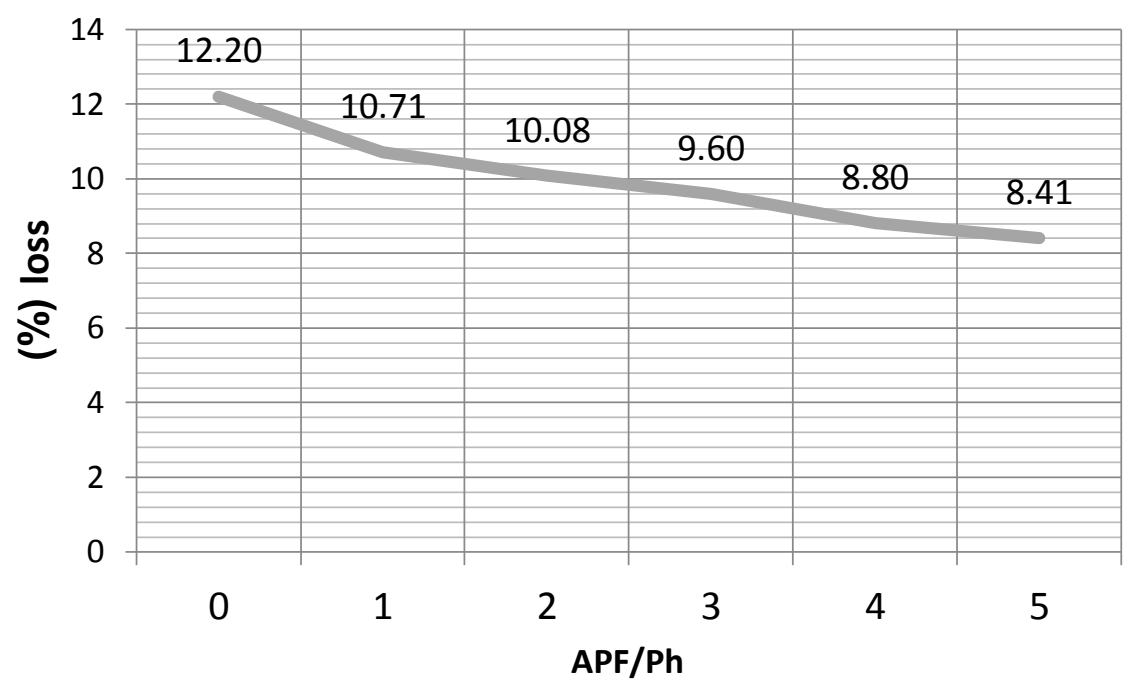

Fig. 15: Harmonic loss in terms of the number of active power filters in each phase.

In Table 7 whichever index is bigger, the proportion of energy saving to cost of APFs procurement makes it more economical. In other words, the funds for APF procurement are consumed sooner. So in ascending order, stages of 1, 2, 5, 3 and 4 have faster asset returns.

\section{CONCLUSION}

Harmonic current and voltage levels increase in distribution systems daily, the main reason for the mentioned problem, is increasing in devices that produce harmonics. Thyristor controller devices are the samples that are used extensively in industrial, commercial, and residential zones. These devices are used for controlling the voltage, the velocity of frequency changes, and the power models. Because of their lower price, greater output, and easier upkeep, they are generally substituted for other devices. In this paper, the results of the practical test on the SAJJAD feeder in Ghaemshahar city from the harmonic viewpoint were presented that confirmed the existence of harmonic distortion. The results also indicate the necessity of studying monitoring politics and the crimes of harmonic producers. Then, using a BBO algorithm, suitable locations and sizes for APFs on the feeder were studied was calculated. Results show the decrease of losses up to $3.79 \%$ in all studied feeders. Then an index for economic advantage through the return on assets was chosen and was compared for different numbers of APF and loss reduction in each stage was presented. From the voltage profile viewpoint, voltage drops that compensated for the LV feeders that damage devices in distribution system were extremely decreased.

\section{REFERENCES}

[1] Wanger VE. (1993). Effects of harmonics on equipment. IEEE Transactions on Power Delivery, 8(2):672-680.

[2] Montoya FG, García-Cruz A, Montoya MG, Manzano-Agugliaro F. (2016). Power quality techniques research worldwide: A review. Renewable and Sustainable Energy Reviews, 54: 846-856.

[3] Lembo F,. D'onofrio VH. (1985) The Effects of Power System Harmonics on Power System Equipment and Loads, IEEE Transactions on Power Apparatus and Systems, vol. PAS-104, no. 9 , pp. 2555-2563. 
[4] Dwyer R, Khan AK, Mcgranaghan M, Tang L, Mccluskey RK, Sung R, Houy T. (1995) Evaluation of harmonic impacts from compact fluorescent lights on distribution systems. IEEE Trans. on Power Systems, 10(4):1772-1779.

[5] Mahela OP, Shaik AG. (2016). Topological aspects of power quality improvement techniques: A comprehensive overview. Renewable and Sustainable Energy Reviews, 58:1129-1142.

[6] Akagi H. (1996). New trends in active filters for power conditioning. IEEE Transactions on Industry Applications, 32(6):1312-1322.

[7] Chen Jiang, Salles D, Xu W, Freitas W. (2012) Assessing the Collective Harmonic Impact of Modern Residential Loads-Part II: Applications. IEEE Transactions on Power Delivery, 27(4):1947-1955

[8] Jinwei He, Yun Wei Li, Blaabjerg F, Xiongfei Wang. (2014) Active Harmonic Filtering Using Current-Controlled, Grid-Connected DG Units With Closed-Loop Power Control, IEEE Transactions on Power Electronics, 29(2):642-653

[9] Ying-Pin Chang, Chinyao Low, Shih-Yu Hung. (2009) Integrated feasible direction method and genetic algorithm for optimal planning of harmonic filters with uncertainty conditions Expert Systems with Applications, 36:3946-3955

[10] Esfahani MT, Hosseinian SH, Vahidi B. (2015) A new optimal approach for improvement of active power filter using FPSO for enhancing power quality. International Journal of Electrical Power \& Energy Systems, 69:188-199.

[11] Dash SK, Panda G, Ray PK, Pujari SS. (2016) Realization of active power filter based on indirect current control algorithm using Xilinx system generator for harmonic elimination. International Journal of Electrical Power \& Energy Systems, 74:420-428.

[12] Fujita H, Akagi H. (1991) Design strategy for the combined system of shunt passive and series active filters. In Proceedings of the IEEE industry applications society annual meeting (pp. 898-903).

[13] Reza Keypour, Hossein Seifi, Ali Yazdian-Varjani. (1999) Active power line conditioner planning using an enhanced optimal harmonic power flow method. Electric Power Systems Research, 52:181-188.

[14] Singh SK, Sinha N, Goswami AK, Sinha N. (2016) Power system harmonic estimation using biogeography hybridized recursive least square algorithm. International Journal of Electrical Power \& Energy Systems, 83:219-228.

[15] Ghaffarzadeh N, Sadeghi H. (2016) A new efficient BBO based method for simultaneous placement of inverter-based DG units and capacitors considering harmonic limits. International Journal of Electrical Power \& Energy Systems, 80:37-45.

[16] Simon D. (2008) Biogeography-Based Optimization, IEEE Transactions on Evolutionary Computation, 12(6):702-713. 


\section{APPENDIX}

Table A1: Values of effective current harmonics of the feeder that is studied and the scale of their loses (entry of the software)

\begin{tabular}{|c|c|c|c|c|c|c|c|c|c|c|c|}
\hline $\begin{array}{c}\text { Harmonic } \\
\text { losses (VA) }\end{array}$ & $\begin{array}{c}\text { Voltage } \\
\text { (V) }\end{array}$ & $\begin{array}{c}\text { THDIe } \\
\text { (A) }\end{array}$ & 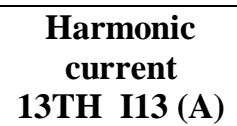 & 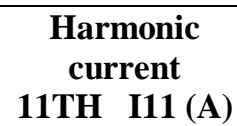 & $\begin{array}{c}\text { Harmonic } \\
\text { current } \\
\text { 7TH I7 (A) }\end{array}$ & $\begin{array}{c}\text { Harmonic } \\
\text { current } \\
\text { 5TH I5 (A) }\end{array}$ & $\begin{array}{c}\text { current } \\
\text { (A) }\end{array}$ & $\begin{array}{c}\text { Reactive } \\
\text { power } \\
\text { (KVAR) }\end{array}$ & $\begin{array}{l}\text { Active } \\
\text { power } \\
(\mathbf{K W})\end{array}$ & ph & $\begin{array}{c}\text { Substation } \\
\text { name }\end{array}$ \\
\hline 10745.54 & 223.4 & 48.10 & 1.39 & 2.11 & 20.21 & 43.57 & 311 & 13.67 & 68.22 & $\mathrm{R}$ & \multirow{3}{*}{ Sajjad } \\
\hline 10212.835 & 226.7 & 45.05 & 4.14 & 5.08 & 17.75 & 40.88 & 269 & 11.72 & 60.08 & $\mathrm{~S}$ & \\
\hline 11116.19 & 227 & 48.97 & 3.35 & 4.06 & 18.64 & 44.98 & 339 & 16.09 & 75.45 & $\mathrm{~T}$ & \\
\hline 15897.168 & 225.3 & 70.56 & 7.65 & 11.21 & 25.34 & 64.44 & 247 & 27.3 & 48.60 & $\mathrm{R}$ & \multirow{3}{*}{ Ranjbar } \\
\hline 2645.874 & 227.7 & 11.62 & 0.99 & 3.21 & 1.57 & 11.01 & 187 & 21.4 & 36.90 & $\mathrm{~S}$ & \\
\hline 2927.898 & 229.1 & 12.78 & 2.64 & 5.31 & 5.31 & 10 & 160 & 18.6 & 31.80 & $\mathrm{~T}$ & \\
\hline 4272.864 & 225.6 & 18.94 & 0.58 & 1.42 & 8.16 & 17.02 & 114 & 13.18 & 22.27 & $\mathrm{R}$ & \multirow{3}{*}{ Tavakkoli } \\
\hline 3822.63 & 228.9 & 16.70 & 1.35 & 4.11 & 2.3 & 15.97 & 147 & 14.40 & 30.55 & $\mathrm{~S}$ & \\
\hline 17814.72 & 224 & 79.53 & 3.22 & 10.31 & 44.10 & 65.30 & 299 & 24.96 & 62.18 & $\mathrm{~T}$ & \\
\hline 10693.908 & 228.6 & 46.78 & 4.12 & 12.42 & 22.86 & 38.66 & 120 & 13.9 & 23.70 & $\mathrm{R}$ & \multirow{3}{*}{ Zeitun } \\
\hline 15440.225 & 227.9 & 67.75 & 3.07 & 8.58 & 37.83 & 55.46 & 83 & 11.8 & 14.80 & $\mathrm{~S}$ & \\
\hline 9049.185 & 229.5 & 39.43 & 0.76 & 2.27 & 18.70 & 34.63 & 106 & 12.4 & 21.10 & $\mathrm{~T}$ & \\
\hline 3646.05 & 223 & 16.35 & 1.08 & 3.42 & 1.23 & 15.90 & 293 & 27.11 & 59.51 & $\mathrm{R}$ & \multirow{3}{*}{ Malekshah } \\
\hline 3017.28 & 224.5 & 13.44 & 1.56 & 3.08 & 2.87 & 12.67 & 230 & 24.61 & 45.60 & $\mathrm{~S}$ & \\
\hline 2177.175 & 223.3 & 9.75 & 0.55 & 1.65 & 1.42 & 9.49 & 230 & 24.61 & 45.35 & $\mathrm{~T}$ & \\
\hline 11210.82 & 227.4 & 49.30 & 1.09 & 3.14 & 23.39 & 43.27 & 456 & 55.1 & 87.98 & $\mathrm{R}$ & \multirow{3}{*}{ Rezayi } \\
\hline 7625.915 & 227.3 & 33.55 & 2.62 & 1.72 & 26.14 & 20.80 & 524 & 52.79 & 106.8 & $\mathrm{~S}$ & \\
\hline 9023.17 & 223.9 & 40.30 & 4.04 & 7.12 & 15.34 & 36.36 & 604 & 64.17 & 119.2 & $\mathrm{~T}$ & \\
\hline 5075.813 & 226.7 & 22.39 & 2.55 & 2.24 & 7.18 & 20.93 & 174 & 12.1 & 37.70 & $\mathrm{R}$ & \multirow{3}{*}{ Mosalla } \\
\hline 4936.968 & 215.4 & 22.92 & 2.44 & 4.38 & 9.13 & 20.42 & 148 & 8.8 & 30.70 & $\mathrm{~S}$ & \\
\hline 4974.225 & 228.7 & 21.75 & 3.85 & 7.19 & 3.06 & 19.93 & 186 & 13.7 & 40.40 & $\mathrm{~T}$ & \\
\hline 2777.418 & 230.3 & 12.06 & 1.29 & 1.57 & 3.55 & 11.34 & 105 & 8.6 & 22.6 & $\mathrm{R}$ & \multirow{3}{*}{ Pishkar } \\
\hline 1217.216 & 228.8 & 5.32 & 0.71 & 0.93 & 1.44 & 4.99 & 50 & 9.3 & 16.7 & $\mathrm{~S}$ & \\
\hline 1390.637 & 229.1 & 6.07 & 0.62 & 0.78 & 2.01 & 5.64 & 47 & 9.2 & 15.60 & $\mathrm{~T}$ & \\
\hline 9085.395 & 225.5 & 40.29 & 9.6 & 5.82 & 17.97 & 34.27 & 418 & 38.72 & 86.1 & $\mathrm{R}$ & \multirow{3}{*}{ kiosk } \\
\hline 9164.32 & 225.5 & 40.64 & 5.36 & 4.91 & 16.98 & 36.2 & 447 & 48.2 & 87.2 & $\mathrm{~S}$ & \\
\hline 8590.314 & 221.8 & 38.73 & 4.98 & 4.53 & 23.10 & 30.35 & 453 & 40.73 & 92.07 & $\mathrm{~T}$ & \\
\hline 6002.892 & 232.4 & 25.83 & 3.38 & 4.18 & 9.12 & 23.56 & 380 & 38.59 & 79.68 & $\mathrm{R}$ & \multirow{3}{*}{ Square } \\
\hline 5735.205 & 220.5 & 26.01 & 2.23 & 2.62 & 15.12 & 20.88 & 360 & 28.5 & 74.2 & $\mathrm{~S}$ & \\
\hline 6956.196 & 219.3 & 31.72 & 3.13 & 3.88 & 16.56 & 26.59 & 436 & 38.48 & 87.57 & $\mathrm{~T}$ & \\
\hline
\end{tabular}

